Jurnal Hukum Mimbar Justitia

Fakultas Hukum Universitas Suryakancana

Vol. 6 No. 1 - Juni 2020, hlm. 1-28.

ISSN: 2477-5681 (Cetak), ISSN: 2580-0906 (Online)

Open Access at: https://jurnal.unsur.ac.id/jmi

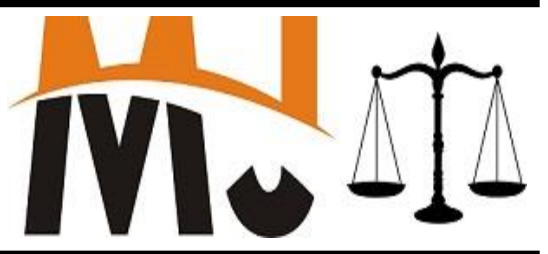

\title{
PELAKSANAAN DISKRESI APARATUR SIPIL NEGARA DALAM RANGKA PENEGAKAN HUKUM
}

\author{
Rossi Suparman \\ Sekolah Tinggi Ilmu Kesehatan Kuningan \\ Email: rossisuparman@yahoo.com
}

Masuk: Maret 2020

Penerimaan: April 2020

Publikasi: Juni 2020

\begin{abstract}
ABSTRAK
Disekresi sebagai suatu tindakan atau keputusan yang dapat digunakan oleh aparatur sipil negara (ASN) dalam kondisi tertentu, dalam menjalankan tugas penegakan hukum pegawai negeri terutama kepolisian kewenangan mengggunakan diskresi dapat diterapkan sesuai kondisi yang diperlukan dalam rangka penegakan hukum, namun pasca berlakunya Undang-Undang Nomor 30 Tahun 2014 tentang Administrasi Pemerintahan butuh kejelasan mengenai kedudukan diskresi dalam penegak hukum. Metode yang digunakan adalah pendekatan normative dengan menggunakan data sekunder dan primer yang dianalisis secara kualitatif. Hasil penelitian menunjukan (1) Bahwa diberlakukannya Undang-Undang Administrasi Pemerintahan merupakan bentuk upaya memberikan kedudukan hukum bagi diskresi yang ada di lingkungan Aparatur Sipil Negara. Diskresi diatur lebih jelas, dari definisi, batasan sesuai undangundang, batasan dikeluarkan oleh Pejabat yang berwenang, tujuan, lingkup, syarat, penggunaan diskresi dan prosedur persetujuan, dan akibat hukum diskresi. (2) POLRI dalam kedudukannya sebagai aparat penegak hukum mempunyai fungsi menegakkan hukum di bidang yudisial baik itu yang bersifat preventif maupun represif. Sehingga dengan dimilikinya kewenangan diskresi dibidang yudisial yang tertuang dalam UU No 2 tahun 2002 pada Pasal 18 ayat (1) bahwa "Untuk kepentingan umum pejabat Kepolisian Negara Republik Indonesia dalam melaksanakan tugas dan wewenangnya dapat bertindak menurut penilaiannya sendiri". (3) bahwa dalam hubungan antara pelaksanaan diskresi menurut Undang-Undang Administrasi Pemerintahan dengan Undang-undang Kepolisian Republik Indonesia adalah terdapat perluasan tujuan diskresi kepolisian dalam penegakan hukum, yaitu tidak hanya untuk menciptakan dan memelihara keamanan dan ketertiban, melainkan juga untuk melancarkan dan mengatasi hambatan dalam proses penegakan hukum.
\end{abstract}

Kata Kunci : Diskresi, Aparatur Sipil Negara, Penegakan Hukum. 


\section{ABSTRACT}

Secreted as an action or decision that can be used by the state civil service (ASN) under certain conditions, in carrying out the law enforcement duties of civil servants especially the police the authority to use discretion can be applied according to the conditions needed in the context of law enforcement, but after the enactment of Law Number 30 of 2014 concerning Government Administration requires clarity regarding the position of discretion in law enforcement. The method used is a normative approach using secondary and primary data that is analyzed qualitatively. The results showed (1) That the enactment of the Law on Government Administration is an effort to provide a legal position for discretion within the State Civil Apparatus. Discretion is regulated more clearly, from the definition, the limit according to the law, the limit is issued by the authorized official, the purpose, scope, conditions, use of discretion and approval procedures, and the consequences of discretionary law. (2) POLRI in its position as a law enforcement apparatus has the function of enforcing law in the judicial field both preventive and repressive. So with the discretionary authority in the judicial field as stipulated in Law No. 2 of 2002 in Article 18 paragraph (1) that "In the public interest of the Republic of Indonesia National Police officials in carrying out their duties and authorities can act according to their own judgment". (3) that in the relationship between the implementation of discretion according to the Government Administrative Law and the Police Law of the Republic of Indonesia there is an expansion of the purpose of police discretion in law enforcement, which is not only to create and maintain security and order, but also to launch and overcome obstacles in the process of law enforcement.

Keywords : Discretion, State Civil Apparatus, Law Enforcement.

\section{PENDAHULUAN}

Negara merupakan organisasi tertinggi diantara satu kelompok atau beberapa kelompok masyarakat yang mempunyai cita-cita untuk bersatu hidup didalam daerah tertentu, dan mempunyai pemerintahan yang berdaulat. $^{1}$ Tanti Kirana Utami mengemukakan Negara kesatuan

1 Moh Mahfud MD, 2000, Dasar dan Struktur Ketatanegaraan Indonesia (Edisi Revisi), Renaka Cipta, Jakarta, hlm. 64.
Republik Indonesia merupakan Negara hukum berdasarkan Pancasila dan Undang-Undang Dasar Republik Indonesia Tahun 1945, yang memiliki tujuan mewujudkan kehidupan negara dan bangsa yang adil, sejahtera, aman, tentram, dan tertib, serta menjamin kedudukan hukum yang sama bagi masyarakat. Negara hukum yang dianut di Indonesia adalah negara hukum yang demokratis yang tercermin dalam Undang-Undang Dasar 1945 Pasal 1 
ayat (1) yang menyebutkan bahwa:

“Negara Indonesia adalah Negara

Kesatuan yang berbentuk Republik",

ayat (2) menyebutkan: "Kedaulatan

berada di tangan rakyat dan dilaksanakan menurut Undang-Undang Dasar, dan ayat (3)nya menyebutkan bahwa: "Negara Indonesia adalah negara hukum". ${ }^{2}$ Menurut Zevenbergen, sumber hukum adalah sumber terjadinya hukum atau sumber yang menimbulkan hukum. Dengan kata lain fungsi hukum harus diatur dalam hukum dasar suatu negara yang disebut konstitusi. ${ }^{3}$ Sistem hukum harus sesuai dengan ide yang dicitacitakan. Hukum merupakan alat tujuan negara. ${ }^{4}$ Pound lebih banyak menekankan arti dan fungsi pembentukan hukum yaitu bahwa

2 Tanti Kirana Utami, 2013, Peran Serikat Pekerja Dalam Penyelesaian Perselisihan Pemutusan Hubungan Kerja, Jurnal Wawasan Hukum, Vol. 28 No. 1, Sekolah Tinggi Hukum Bandung, Bandung, hlm. 675.

3 Henny Nuraeny, 2017, Tindak Pidana Perdagangan Orang dalam Prespektif Hak Asasi Manusia, Rajawali, Jakarta Pusat, hlm. 37.

4 Ahmad Hunaeni Zulkarnaen, 2016, Cita Hukum Positif Indonesia dan Asean Economic Community (AEC), Jurnal Hukum Mimbar Justitia, Vol. 2 No. 1, Fakultas Hukum Universitas Suryakancana, Cianjur, hlm. 703. hukum harus memajukan kepentingan umum. Statement inilah yang kemudian dikenal dengan teorinya "Iaw as a tool of social engineering" (hukum sebagai alat atau sarana rekayasa/pembaharuan sosial). ${ }^{5}$

Menurut C.S.T Kansil, hukum mengabdi pada tujuan Negara yaitu mendatangkan kemakmuran dan kebahagiaan bagi rakyatnya. Tujuan negara tersebut dengan menyelenggarakan keadilan dan ketertiban. $^{6}$

Sebagai penganut paham negara kesejahteraan (welfare state) tentunya

Pemerintahan Negara Indonesia tampil aktif untuk ikut campur dalam berbagai aspek kehidupan masyarakat. ${ }^{7}$ Tugas negara menurut paham modern sekarang ini (Negara Kesejahteraan

5 M. Rendi Aridhayandi dkk, 2016, Teori Hukum Lanjutan, Logoz Publishing, Bandung, hlm. 142-143.

6 M. Rendi Aridhayandi, 2019, Kewenangan Pemerintah Daerah Dalam Pembinaan dan Pengawasan Indikasi Geografis Beras Pandanwangi Cianjur, Disertasi, Program Pascasarjana Doktor Ilmu Hukum Universitas Katolik Parahyangan, Bandung, hlm. 2.

7 Patuan Sinaga, Hubungan Antara Kekuasaan dengan Pouvoir Discretionnere dalam Penyelenggaraan Pemerintahan, dalam S.F Marbun dkk., 2004, DimensiDimensi Pemikiran Hukum Administrasi Negara, UII Press, Yogyakarta, hlm. 73. 
atau Social Service State), adalah menyelenggarakan kepentingan umum untuk memberikan kemakmuran dan kesejahteraan yang sebesar-besarnya berdasarkan keadilan dalam suatu Negara Hukum. ${ }^{8}$

Pemerintah memiliki kewenangan untuk membuat suatu produk hukum sebagai salah satu alat untuk menjalankan pemerintahannya. Dalam menciptakan suatu produk hukum telah terbagi dua jenis yaitu yang pertama berupa peraturan (regeling) dan yang kedua berupa keputusan (beschikking). Suatu peraturan (regeling) bersifat mengatur ketentuan-ketentuan umum dalam menjalankan suatu kebijakan atau pemerintahan. Sedangkan suatu keputusan (beschikking) lebih bersifat konkret, individul dan final. Bersifat konkret artinya objek yang diputuskan dalam keputusan tata usaha negara tersebut tidak abstrak tetapi berwujud tertentu atau dapat ditentukan. Bersifat individual artinya keputusan tata usaha negara itu tidak ditujukan

8 Amrah Muslimin, 1985, Beberapa Asas dan Pengertian Pokok Tentang Administrasi dan Hukum Administrasi, Alumni, Bandung, hlm. 110. untuk umum, tetapi tertentu, baik alamat maupun hal yang dituju. Bersifat final artinya sudah definitif, dan karenanya dapat menimbulkan akibat hukum tertentu. $^{9}$

Dalam negara hukum, wewenang pemerintahan berasal dari peraturan perundang-undangan yang berlaku. Menurut R.J.H.M. Huisman yang diterjemahkan dalam buku Ridwan, HR $:{ }^{10}$ "Organ pemerintahan tidak dapat menganggap bahwa ia memiliki sendiri wewenang pemerintahan. Kewenangan hanya diberikan oleh Undang- undang. Pembuat Undang-undang dapat memberikan wewenang pemerintahan tidak hanya kepada organ pemerintahan, tetapi juga terhadap para pegawai (misalnya inspektur pajak, inspektur lingkungan, dan sebagainya) atau terhadap badan khusus (seperti dewan pemilihan umum, pengadilan khusus untuk perkara sewa tanah, atau bahkan terhadap badan hukum privat".

9 Muchsan, 2007, Sistem Pengawasan Terhadap Perbuatan Aparat Pemerintah dan PTUN, Liberty, Yogyakarta, hlm. 60.

10 Ridwan, H.R., 2003, Hukum Administrasi Negara, UII Press, Yogyakarta, hlm. 72-73. 
Rossi Suparman

Jurnal Hukum Mimbar Justitia

Vol. 6 No. 1 - Juni 2020

\section{Pegawai Negeri Sipil (PNS)}

merupakan bagian masyarakat dari sebuah negara. Seperti tertuang pada Pasal 1 ayat 1 Undang-Undang Nomor 43 Tahun 1999 tentang Perubahan atas Undang-Undang Nomor 8 Tahun 1974 tentang Pokok-Pokok Kepegawaian bahwa yang dimaksud Pegawai Negeri adalah setiap warga negara Republik Indonesia yang telah memenuhi syarat yang ditentukan, diangkat oleh pejabat yang berwenang dan diserahi tugas dalam suatu jabatan negeri, atau diserahi tugas negara lainnya, dan digaji berdasarkan peraturan perundangundangan yang berlaku. Sebagai bagian dari sebuah negara, hubungan hukum (rechts betrekking) antara Pegawai Negeri dengan negara merupakan hubungan dinas publik. Hubungan dinas publik timbul semenjak seseorang mengikat dirinya untuk tunduk pada perintah untuk melakukan suatu atau beberapa macam jabatan tertentu. ${ }^{11}$

Hubungannya berkaitan dengan kedudukan PNS dalam menjalankan tugasnya sebagai aparatur negara dan

11 Muchsan, 1988, Pengangkatan Dalam Pangkat Pegawai Negeri Sipil, cetakan kedua, Liberty, Yogyakarta, hlm. 9. pemerintah. Pasal 3 ayat (1) Undangundang Nomor 43 Tahun 1999, mengatur kedudukan PNS yaitu sebagai aparatur negara yang bertugas untuk memberikan pelayanan kepada masyarakat secara profesional, jujur, adil dan merata dalam penyelenggaraan tugas negara, pemerintah dan pembangunan. Rumusan kedudukan PNS didasarkan pada pokok-pokok pikiran bahwa pemerintah tidak hanya menjalankan fungsi umum pemerintah, tetapi juga harus mampu melaksanakan fungsi pembangunan atau dengan kata lain pemerintah bukan hanya menyelenggarakan tertib pemerintahan, tetapi juga harus mampu menggerakkan dan memperlancar pembangunan untuk kepentingan rakyat. ${ }^{12}$

Dalam perspektif tata kelola pemerintahan, setiap badan atau pejabat pemerintahan dalam menjalankan tanggung jawabnya wajib melaksanakan asas-asas umum pemerintahan yang baik. Dengan

12 C.S.T. Kansil, 1979, Pokok-Pokok Hukum Kepegawaian Republik Indonesia, Pradnya Paramitha, Jakarta, hlm. 38. 
Rossi Suparman

Jurnal Hukum Mimbar Justitia

Vol. 6 No. 1 - Juni 2020

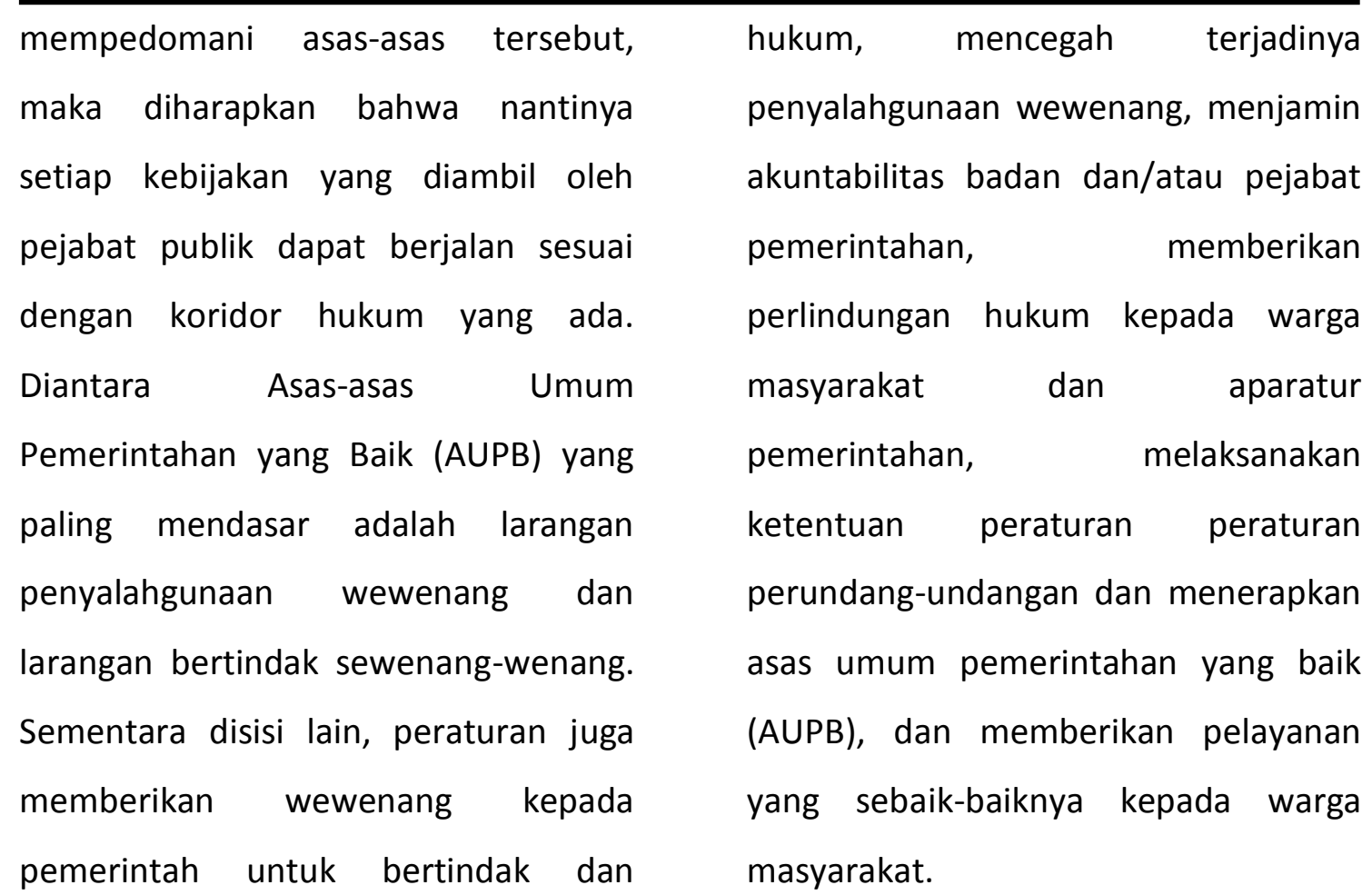
membuat suatu aturan hukum yang menyimpang dari asas legalitas. Inilah yang kemudian disebut dengan istilah diskresi (bahasa Jerman: Freies Ermessen).

Istilah diskresi dapat ditemukan dalam Undang-Undang Nomor 30 Tahun 2014 tentang Administrasi Pemerintahan. Berdasarkan informasi yang didapatkan dari laman resmi Sekretariat Kabinet Republik Indonesia, kehadiran Undang - Undang yang terdiri atas 89 pasal ini dimaksudkan untuk menciptakan tertib penyelenggaraan administrasi pemerintahan, menciptakan kepastian

Menurut Pasal 1 ayat 9 UndangUndang Nomor 30 Tahun 2014, "Diskresi adalah keputusan dan/atau tindakan yang ditetapkan dan/atau dilakukan oleh pejabat pemerintahan untuk mengatasi persoalan konkret yang dihadapi dalam penyelenggaraan pemerintahan dalam hal peraturan perundang-undangan yang memberikan pilihan, tidak mengatur, tidak lengkap atau tidak jelas, dan/atau adanya stagnasi pemerintahan."

Menggunakan diskresi sesuai dengan tujuannya merupakan salah satu hak yang dimiliki oleh pejabat pemerintahan dalam mengambil 
Rossi Suparman

Jurnal Hukum Mimbar Justitia

Vol. 6 No. 1 - Juni 2020

keputusan dan/atau tindakan.

Demikian yang diatur dalam Pasal 6 ayat 1 dan 2(e) Undang-Undang Nomor 30 Tahun 2014. ${ }^{13} \quad$ Pejabat pemerintahan yang melakukan diskresi disini adalah unsur yang melaksanakan fungsi pemerintahan. Contoh sederhana dari diskresi yang jelas dan dapat kita lihat dalam kehidupan sehari-hari adalah seorang polisi lalu lintas yang mengatur lalu lintas di suatu perempatan jalan, yang mana hal ini sebenarnya sudah diatur oleh lampu pengatur lalu lintas (traffic light). Menurut Undang Undang Lalu Lintas, polisi dapat menahan kendaraan dari satu ruas jalan meskipun lampu hijau atau mempersilakan jalan kendaraan meskipun lampu merah. Demikian contoh yang disebut dalam laman resmi Kementerian Pendayagunaan Aparatur Negara dan Reformasi Birokrasi (KemenPAN-RB).

Diskresi dimaknai sebagai "kemerdekaan dan/atau kewenangan dalam membuat keputusan untuk mengambil tindakan yang dianggap tepat atau sesuai dengan situasi dan

13 Undang -Undang Nomor 30 Tahun 2014 tentang Administrasi Pemerintahan. kondisi yang dihadapi secara bijaksana dan dengan memperhatikan segala pertimbangan maupun pilihan yang memungkinkan. ${ }^{14}$ Diskresi diartikan sebagai kebebasan mengambil keputusan dalam setiap situasi yang dihadapi menurut pendapatnya sendiri. $^{15}$

Salah satu contoh kasus mengenai penerapan diskresi adalah kasus yang menimpa Dahlan Iskan. Beliau ditetapkan tersangka kasus aset Perseroan Terbatas (PT) Panca Wira Usaha (PWU) berdasarkan surat perintah penyidikan berNomor Print1198/O.5/Fd.1/10/2016 tertanggal 27

Oktober 2016. Dengan diduga melakukan pelanggaran pada penjualan aset PT. PWU di Kediri dan Tulungagung pada Tahun 2003. Dahlan diminta oleh Gubernur Jawa Timur untuk menyelamatkan perusahaan Badan Usaha Milik Daerah (BUMD) milik Jawa Timur itu dari kebangkrutan. Gubernur Jawa Timur memintanya untuk

14 Erlyn, 2000, Diskresi Polisi, Lembaga Penerbit Universitas Diponegoro, Semarang, hlm. 17.

15 Simorangkir, dkk, 2004, Kamus Hukum, Sinar Grafika.Susanto, Jakarta, dalam Anthon F, 2010, Wajah Peradilan Kita, Refika Aditama, Bandung, hlm. 5. 
Rossi Suparman

Jurnal Hukum Mimbar Justitia

Vol. 6 No. 1 - Juni 2020

mengubah kondisi PT. PWU secara drastis dan dijalankan seperti perusahaan swasta. Berdasarkan keputusan Dewan Perwakilan Rakyat Daerah (DPRD) Provinsi Jawa Timur, akhirnya pengelolaan perusahaan BUMD itu berubah menjadi Perseroan Terbatas (PT). Kendati telah berubah menjadi PT, Dahlan mengaku tetap berhati-hati dalam pelaksanaan pelepasan aset.

Telah mengaku meminta persetujuan ke DPRD Jatim melalui surat yang dikirimkan pada 2 Maret 2002 dan baru dibalas bulan September 2002. Dalam jawabannya, DPRD Jatim meminta Dahlan Iskan untuk menjalankan roda perusahaan dengan berpegang pada undang-undang perseroan dan tanpa persetujuan DPRD Jatim lagi.

Jika dilihat berdasarkan prosedur penggunakan dikresi yang diatur dalam Undang-Undang Nomor 30 Tahun 2014 Pasal 26 ayat 2 yang berbunyi : "Pejabat yang menggunakan diskresi sebagaimana dimaksud pada ayat (1) wajib menyampaikan permohonan persetujuan secara tertulis kepada atasan pejabat", dalam hal ini Dahlan Iskan telah meminta persetujuan kepada DPRD Jawa Timur. "DPRD Jatim meminta Dahlan Iskan untuk menjalankan roda perusahaan dengan berpegang pada undang-undang perseroan dan tanpa persetujuan DPRD Jatim lagi" dari pernyataan tersebut tentunya DPRD Jatim telah menyetujui penggunaan diskresi tersebut.

Hal ini karena DPRD meminta Dahlan Iskan untuk menjalankan roda PT. PWU tanpa persetujuan DPRD lagi. Walaupun BUMD Jawa Timur telah berubah statusnya menjadi Perseoran Terbatas, akan tetapi hak milik PT. PWU itu masih dimiliki oleh Jawa Timur, karena PT. PWU merupakan badan usaha milik daerah. Jadi dalam hal ini Dahlan Iskan memiliki keleluasaan dalam mengelola PT. PWU tersebut, selama tidak melampaui batas waktu berlakunya wewenang yang diberikan oleh ketentuan peraturan perundangundangan. Hal ini berdasarkan pasal 30 ayat 1 huruf (a) Undang -Undang Nomor 30 Tahun 2014. Jika melampaui batas berlakunya wewenang maka diskresi menjadi tidak sah. Ditinjau dari 
Rossi Suparman

Jurnal Hukum Mimbar Justitia

Vol. 6 No. 1 - Juni 2020

sudut hukum, setiap kekuasaan akan dilandasi dan dibatasi oleh ketentuan hukum. Namun, kekuasaan diskresi yang begitu luas dan kurang jelas batasbatasnya akan menimbulkan permasalahan terutama apabila dikaitkan dengan asas-asas hukum pidana yaitu asas kepastian hukum dan Hak Asasi Manusia (HAM).

Selain Aparatur Sipil Negara (ASN), lembaga yang memiliki diskresi adalah lembaga kepolisian. Keberhasilan penyelenggaraan fungsi kepolisian tanpa meninggalkan etika profesi sangat dipengaruhi oleh kinerja polisi yang direfleksikan dalam sikap dan perilaku pada saat menjalankan tugas dan wewenangnya. Berbicara soal diskresi kepolisian dalam sistem peradilan pidana, maka akan ditemukan suatu hubungan antara hukum, diskresi, kepolisian, penyidikan dan sistem peradilan pidana. Maka pokok permasalahan yang akan dikaji pada hakekatnya adalah bekerjanya hukum dan diskresi kepolisian itu. Keterkaitan hukum pidana dengan diskresi yakni, kekuasaan diskresi yang dimiliki polisi justru akan menjadi suatu

$\begin{array}{lcc}\text { permasalahan baru apabila polisi } \\ \text { mengambil tindakan } & \text { tidak }\end{array}$
menegakkan, tetapi memaafkan dan mengenyampingkan, menghentikan atau mengambil tindakan lain diluar proses yang telah ditentukan oleh hukum, sehingga dengan kekuasaan itu seolah-olah justru polisilah yang telah melanggar ketentuan asas- asas hukum pidana.

Dengan identifikasi masalah dalam penelitian ini:

1. Bagaimana Pelaksanaan Diskresi Bagi Aparatur Sipil Negara berdasarkan Undang-Undang Nomor 30 Tahun 2014 tentang Administrasi Pemerintahan?

2. Bagaimana Pelaksanaan Diskresi Bagi Kepolisian berdasarkan Undang-Undang Nomor 2 Tahun 2002 tentang Kepolisian dalam Rangka Penegakan Hukum?

3. Bagaimana Hubungan Pelaksanaan Diskresi Aparatur Sipil Negara dengan Diskresi yang dilakukan oleh Kepolisian?

\section{METODE PENELITIAN}


Rossi Suparman

Jurnal Hukum Mimbar Justitia

Vol. 6 No. 1 - Juni 2020

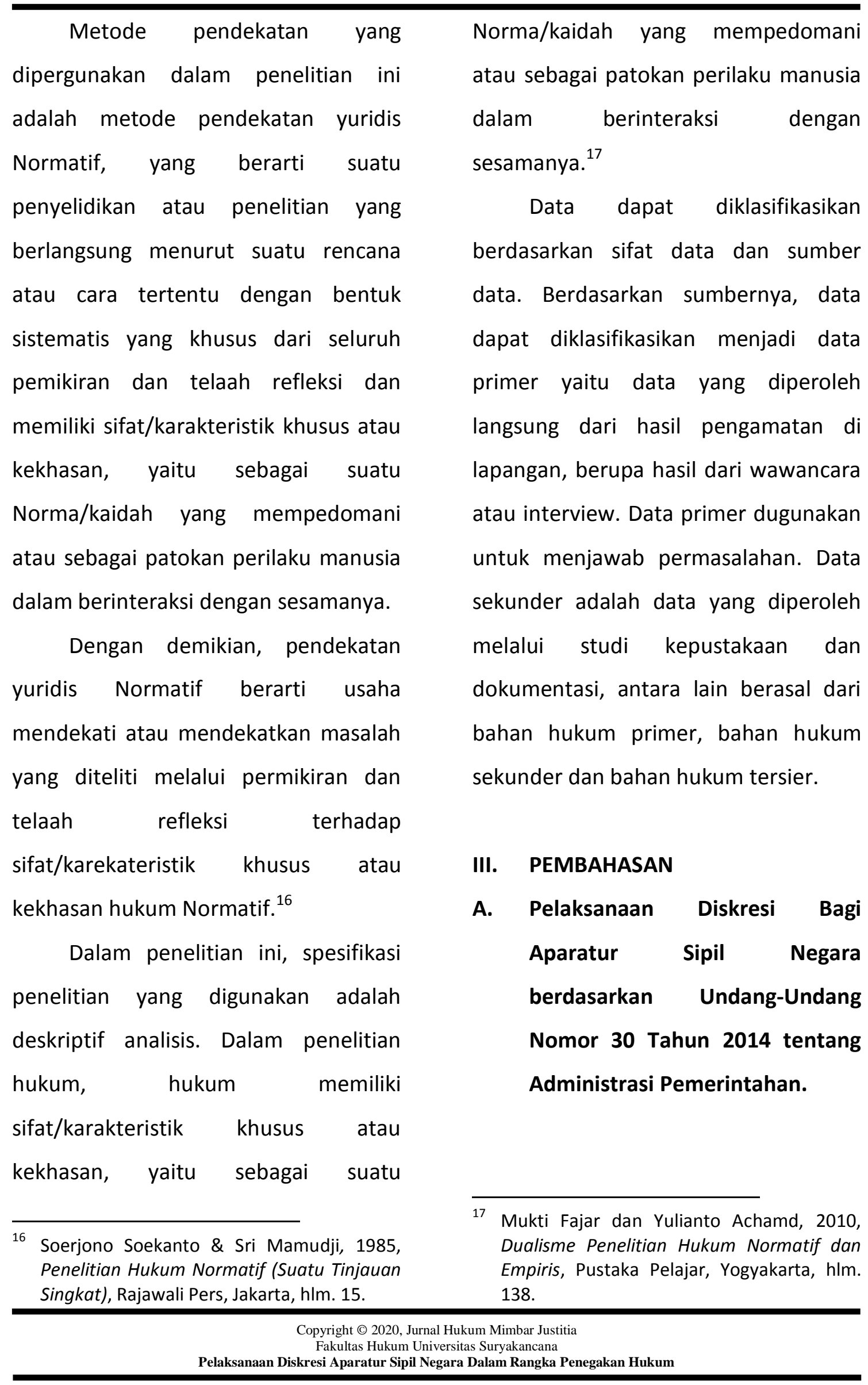


Rossi Suparman

Jurnal Hukum Mimbar Justitia

Vol. 6 No. 1 - Juni 2020

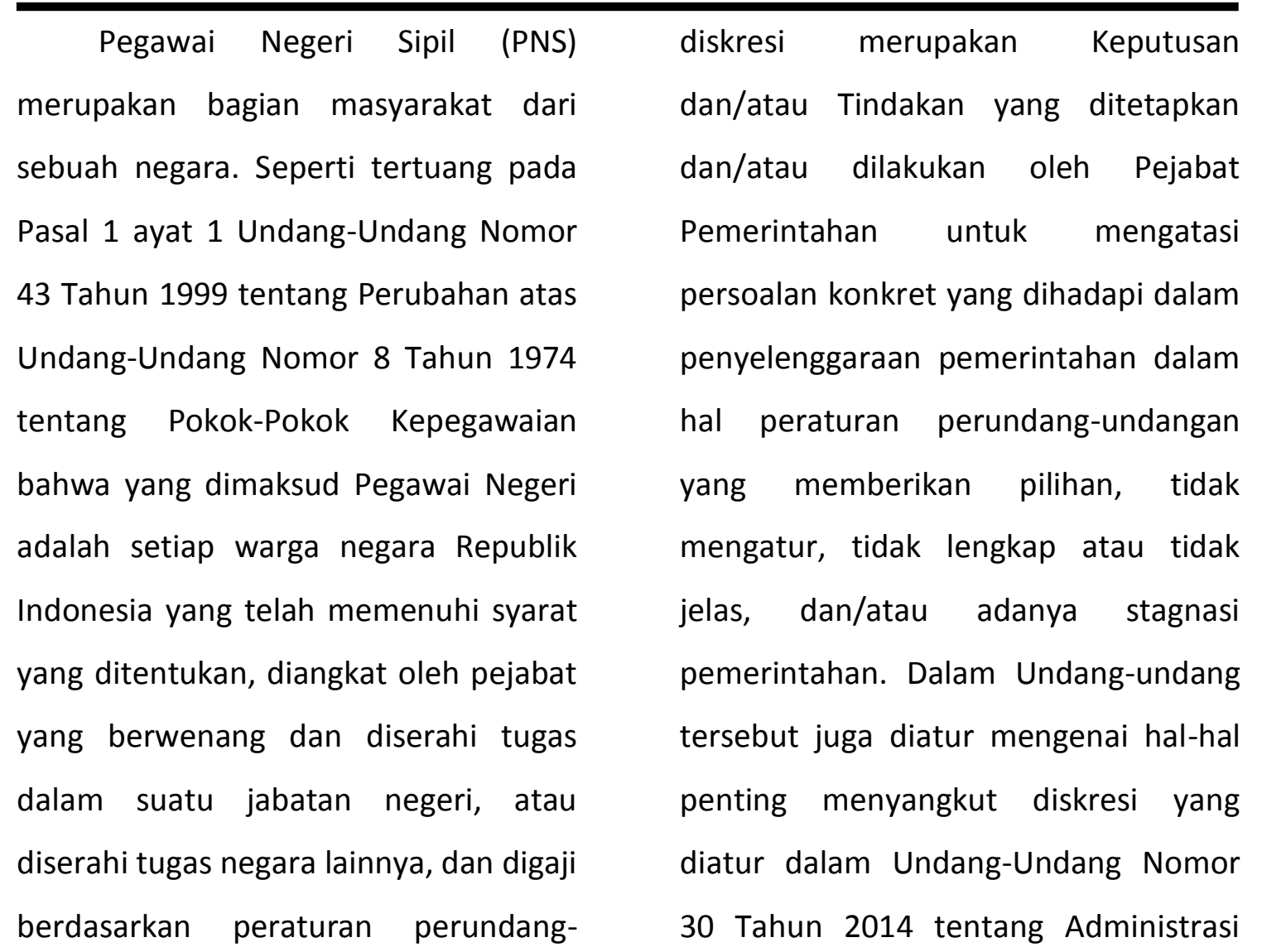
undangan yang berlaku. Sebagai bagian dari sebuah negara, hubungan hukum (rechts betrekking) antara Pegawai Negeri dengan negara merupakan hubungan dinas publik. Hubungan dinas publik timbul semenjak seseorang mengikat dirinya untuk tunduk pada perintah untuk melakukan suatu atau beberapa macam jabatan tertentu. ${ }^{18}$

Diskresi apabila dilihat dari Pemerintahan antara lain:

1. Diskresi hanya dapat dilakukan oleh pejabat pemerintahan yang berwenang (Pasal 22 ayat (1))

2. Setiap penggunaan diskresi pejabat pemerintahan bertujuan untuk: (Pasal 22 ayat (2) dan penjelasan)

a. melancarkan penyelenggaraan pemerintahan;

kacamata Undang-Undang Nomor 30

b. mengisi kekosongan hukum;

Tahun 2014 tentang Administrasi

c. memberikan kepastian hukum; Pemerintahan menyatakan bahwa dan

18 Muchsan, 1988, Pengangkatan dalam Pangkat...Op.Cit, hlm. 9. 
d. mengatasi stagnasi pemerintahan dalam keadaan tertentu guna kemanfaatan dan kepentingan umum. Adapun yang dimaksud dengan stagnasi pemerintahan adalah tidak dapat dilaksanakannya aktivitas pemerintahan sebagai akibat kebuntuan atau disfungsi dalam penyelenggaraan pemerintahan, contohnya: keadaan bencana alam atau gejolak politik.

3. Diskresi pejabat pemerintahan meliputi (Pasal 23):

a. pengambilan Keputusan dan/atau Tindakan berdasarkan ketentuan peraturan perundang-undangan yang memberikan suatu pilihan Keputusan dan/atau Tindakan;

b. pengambilan Keputusan dan/atau Tindakan karena peraturan perundang-undangan tidak mengatur;

c. pengambilan Keputusan dan/atau Tindakan karena peraturan perundang-undangan tidak lengkap atau tidak jelas; dan

d. pengambilan Keputusan dan/atau Tindakan karena adanya stagnasi pemerintahan guna kepentingan yang lebih luas.

4. Pejabat Pemerintahan yang menggunakan Diskresi harus memenuhi syarat (Pasal 24):

a. sesuai dengan tujuan Diskresi sebagaimana dimaksud dalam Pasal 22 ayat (2);

b. tidak bertentangan dengan ketentuan peraturan perundangundangan;

c. sesuai dengan Asas-asas Umum Pemerintahan yang Baik (AUPB);

d. berdasarkan alasan-alasan yang objektif;

e. tidak menimbulkan Konflik Kepentingan; dan

f. dilakukan dengan iktikad baik.

5. Penggunaan diskresi yang berpotensi mengubah alokasi anggaran wajib memperoleh persetujuan dari atasan pejabat sesuai dengan ketentuan peraturan perundang-undangan. Persetujuan dimaksud dilakukan apabila penggunaan diskresi menimbulkan akibat hukum yang berpotensi membebani keuangan negara (Pasal 25 ayat (1) dan (2)) 
Rossi Suparman

Jurnal Hukum Mimbar Justitia

Vol. 6 No. 1 - Juni 2020

Dalam hal melihat pada contoh kasus pelaksanaan diskresi yang dilakukan oleh Dahlan Iskan yang mana kasus aset Perseroan Terbatas (PT) Panca Wira Usaha (PWU) berdasarkan surat perintah penyidikan bernomor Print-1198/0.5/Fd.1/10/2016

tertanggal 27 Oktober 2016. Dengan diduga melakukan pelanggaran pada penjualan aset PT. PWU di Kediri dan Tulungagung pada Tahun 2003. Dahlan diminta oleh Gubernur Jawa Timur untuk menyelamatkan perusahaan Badan Usaha Milik Daerah (BUMD) milik Jawa Timur itu dari kebangkrutan. Gubernur Jawa Timur memintanya untuk mengubah kondisi PT. PWU secara drastis dan dijalankan seperti perusahaan swasta. Berdasarkan keputusan Dewan Perwakilan Rakyat Daerah (DPRD) Provinsi Jawa Timur, akhirnya pengelolaan perusahaan BUMD itu berubah menjadi Perseroan Terbatas (PT). Kendati telah berubah menjadi PT, Dahlan mengaku tetap berhati-hati dalam pelaksanaan pelepasan aset.

Dia mengaku telah meminta persetujuan ke DPRD Jatim melalui surat yang dikirimkan pada 2 Maret 2002 dan baru dibalas bulan September 2002. Dalam jawabannya, DPRD Jatim meminta Dahlan Iskan untuk menjalankan roda perusahaan dengan berpegang pada undang-undang perseroan dan tanpa persetujuan DPRD Jatim lagi. Jika dilihat berdasarkan prosedur penggunakan dikresi yang diatur dalam Undang -Undang Nomor 30 Tahun 2014 Pasal 26 ayat (2) yang berbunyi: "Pejabat yang menggunakan diskresi sebagaimana dimaksud pada ayat (1) wajib menyampaikan permohonan persetujuan secara tertulis kepada atasan pejabat",

Dalam hal ini Dahlan Iskan telah meminta persetujuan kepada DPRD Jawa Timur. dari pernyataan tersebut tentunya DPRD Jatim telah menyetujui penggunaan diskresi tersebut. Hal ini karena DPRD meminta Dahlan Iskan untuk menjalankan roda PT. PWU tanpa persetujuan DPRD lagi. Walaupun BUMD Jawa Timur telah berubah statusnya menjadi Perseoran Terbatas, akan tetapi hak milik PT. PWU itu masih dimiliki oleh Jawa Timur, karena PT. PWU merupakan badan 
Rossi Suparman

Jurnal Hukum Mimbar Justitia

Vol. 6 No. 1 - Juni 2020

usaha milik daerah. Jadi dalam hal ini

Dahlan Iskan memiliki keleluasaan dalam mengelola PT. PWU tersebut, selama tidak melampaui batas waktu berlakunya wewenang yang diberikan oleh ketentuan peraturan perundangundangan. Hal ini berdasarkan pasal 30 ayat 1 huruf (a) Undang - Undang Nomor 30 Tahun 2014. Jika melampaui batas berlakunya wewenang maka diskresi menjadi tidak sah. Berdasarkan kasus di atas, dapat ditemukannya analisis sebagai berikut: Pertama mengenai kedudukan Dahlan Iskan sebagai direktur yang ditunjuk oleh oleh Gubernur Jawa Timur untuk menyelamatkan perusahaan Badan Usaha Milik Daerah (BUMD) milik Jawa Timur itu dari kebangkrutan. Teknis untuk melakukan penyelamatan perusahaan tersebut tentu dilakukan beberapa strategi. Salah satunya adalah dengan cara menjual beberapa aset yang sudah tidak produktif.

Kedua mengenai status PT. Panca Wira Usaha adalah merupakan Badan Usaha Milik Daerah yang mana keberadaannya diatur dan dilaksanakan menurut Undang-Undang Nomor 5
Tahun 1962 tentang Perusahaan

Daerah.

Keputusan DPRD untuk mengubah pengelolaan PT. Panca Wira Usaha menjadi pengelolaan secara Perseroan tentu menjadikan Perusahaan tersebut juga menjadi diatur dan dilaksanakan menurut Undang-Undang Nomor 40 Tahun 2007 tentang Perseroan Terbatas. Sehingga dampaknya adalah terdapat dua undang-undang yang memiliki konsekuensi teknis yang berbeda dalam kasus ini melalui penjualan asetnya. Yang dilakukan oleh Dahlan Iskan secara Undang-Undang Nomor 40 Tahun 2007 tentang Perseroan Terbatas sudah tepat berkaitan dengan cara pelepasan beberapa aset perusahaan PT. PWU. Namun dari segi Undang-Undang Nomor 5 Tahun 1962 dan Undang-Undang Nomor 30 Tahun 2014 tentang Administrasi Pemerintahan, Dahlan melakukan pelanggaran terkait dengan izin pelepasan aset yang sebelumnya harus disepakati oleh DPRD terkait.

Tindakan Dahlan dalam melepas aset sudah bisa disebut 
Rossi Suparman

Jurnal Hukum Mimbar Justitia

Vol. 6 No. 1 - Juni 2020

sebagai Diskresi yang mana

kedudukannya sebagai Direktur PT.

PWU masih masuk ke dalam ruang lingkup pengaturan Administrasi

Pemerintahan. Namun menurut analisis

penulis, bahwa tindakan yang dilakukan

oleh Dahlan Iskan merupakan sebuah

reduksi hukum. Secara administratif

hukum tata usaha negara, tentu yang

dilakukan Dahlan dapat dikenai sebuah

pelanggaran atas Asas Umum

Pemerintahan yang Baik. Namun disatu

sisi Dahlan menjalankan Perusahaan

tersebut dengan asas professional dari

kacamata perusahaan perseroan

terbatas. Tidak ada pelanggaran dalam

teknis administrasi disana. Maka dari

itu, apabila kini menjadi bias, perlu

dikaji kembali atas nilai kemanfaatan

dari penunjukkan Dahlan sebagai

direktur. Apabila perusahaan tersebut

memang saat ini sudah menjadi lebih

baik, penulis rasa apa yang dilakukan

Dahlan bukan merupakan pelanggaran

mengingat delik tersebut terjadi

sebelum dikeluarkannya Undang-

Undang Nomor 30 tahun 2014 tentang

Administrasi Pemerintahan. Kehadiran

Undang-Undang ini dimaksudkan untuk menciptakan tertib penyelenggaraan

administrasi

pemerintahan,

menciptakan kepastian hukum, mencegah terjadinya penyalahgunaan wewenang, menjamin akuntabilitas badan dan/atau pejabat pemerintahan, memberikan perlindungan hukum kepada warga masyarakat dan aparatur pemerintahan, melaksanakan ketentuan peraturan peraturan perundang-undangan dan menerapkan azas-azas umum pemerintahan yang baik (AUPB), dan memberikan pelayanan yang sebaik-baiknya kepada warga masyarakat.

Berdasarkan gambaran tersebut di atas dapat dilihat bahwa diberlakukannya Undang-Undang Nomor 30 tahun 2014 tentang Administrasi Pemerintahan merupakan bentuk upaya memberikan kedudukan hukum bagi diskresi yang ada di lingkungan Aparatur Sipil Negara. Diskresi diatur lebih jelas, ada dalam 16 Pasal di dalam undang-undang tersebut mulai dari definisi, batasan sesuai undang-undang, batasan dikeluarkan oleh Pejabat yang berwenang, tujuan, lingkup, syarat, penggunaan diskresi 
Rossi Suparman

Jurnal Hukum Mimbar Justitia

Vol. 6 No. 1 - Juni 2020

dan prosedur persetujuan, dan akibat hukum diskresi.

\section{B. Pelaksanaan Diskresi Bagi} Kepolisian berdasarkan UndangUndang Nomor 2 Tahun 2002 tentang Kepolisian dalam Rangka Penegakan Hukum.

Diskresi bagi Kepolisian merupakan hal yang diatur dalam Undang-Undang Nomor 2 Tahun 2002. Berdasarkan data yang ada pada Bab II, menyatakan bahwa Kepolisian adalah segala hal-ihwal yang berkaitan dengan fungsi dan lembaga polisi sesuai dengan peraturan perundangundangan. Hal tersebut diatur dalam Pasal 1 ayat (1) Undang-Undang Nomor 2 Tahun 2002 tentang Kepolisian. Menurut Erma Yulihastin dalam bukunya berjudul: "Bekerja Sebagai Polisi", kata "polisi" dapat merujuk kepada tiga hal, yaitu orang, institusi (lembaga), atau fungsi. Kata polisi yang merujuk kepada "orang" pengertiannya adalah anggota badan pemerintah yang bertugas memelihara keamanan dan ketertiban umum. Kata polisi yang bermakna institusi, biasa disebut dengan kepolisian, contohnya Kepolisian Negara Republik Indonesia atau POLRI, dan Kepolisian Daerah atau Polda. Sedangkan arti polisi sebagai fungsi atau sebagai "kata kerja", berasal dari bahasa inggris "to police", yaitu pekerjaan mengamati, memantau, mengawasi segala sesuatu untuk menangkap gejala yang terjadi ${ }^{19}$

Pengertian kepolisian menurut Van Vollenhoven dalam bukunya berjudul "Politie Overzee" mengatakan bahwa pengertian politie meliputi organ-organ pemerintah yang berwenang dan berkewajiban untuk mengusahakan pengawasan dan pemaksaan jika diperlukan, agar yang diperintah untuk berbuat atau tidak berbuat menurut kewajiban masingmasing. Maka, dari pengertian tersebut makna polisi mengandung arti sebagai organ dan fungsi, yakni sebagai organ pemerintah dengan tugas mengawasi, jika perlu menggunakan paksaan supaya yang diperintah menjalankan dan tidak melakukan larangan perintah. ${ }^{20}$

\footnotetext{
${ }^{19}$ Satjipto Rahardjo, 1983, Masalah Penegakan Hukum, Sinar Baru, Bandung, hlm. 11.

${ }^{20} \mathrm{Ibid}, \mathrm{hlm} .14$.
} 
Rossi Suparman

Jurnal Hukum Mimbar Justitia

Vol. 6 No. 1 - Juni 2020

Berdasarkan data yang ada pada Bab II juga disebutkan tugas pokok kepolisian yang mana pada intinya sebagai alat negara, Kepolisian memiliki fungsi strategis melindungi dan menjalankan ketertiban yang ada pada masyarakat. Dalam Bab II juga disebutkan jika Kepolisian Republik Indonesia memiliki peran dalam memelihara keamanan dan ketertiban masyarakat, menegakkan hukum, serta memberikan perlindungan, pengayoman, dan pelayanan kepada masyarakat dalam rangka terpeliharanya keamanan dalam negeri.

Berdasarkan data yang ada pada Bab II, bahwa Penegakan hukum merupakan suatu usaha untuk mewujudkan ide-ide keadilan, kepastian hukum dan kemanfaatan sosial menjadi kenyataan. Jadi penegakan hukum pada hakikatnya adalah proses perwujudan ide-ide. Penegakan hukum adalah proses dilakukannya upaya tegaknya atau berfungsinya norma-norma hukum secara nyata sebagai pedoman pelaku dalam lalu lintas atau hubungan- hubungan hukum dalam kehidupan bermasyarakat dan bernegara.

Menurut Soerjono Soekanto, penegakan hukum adalah kegiatan menyerasikan hubungan nilai-nilai yang terjabarkan didalam kaidahkaidah/pandangan nilai yang mantap dan mengejewantah dan sikap tindak sebagai rangkaian penjabaran nilai tahap akhir untuk menciptakan, memelihara dan mempertahankan kedamaian pergaulan hidup. Penegakan hukum secara konkret adalah berlakunya hukum positif dalam praktik sebagaimana seharusnya patut dipatuhi. Oleh karena itu, memberikan keadilan dalam suatu perkara berarti memutuskan hukum in concreto dalam mempertahankan dan menjamin ditaatinya hukum materiil dengan menggunakan cara prosedural yang ditetapkan oleh hukum formal. ${ }^{21}$

Undang-undang Nomor 2 Tahun 2002 Pasal 2 tersebut dapat dilihat dengan jelas bahwa POLRI dalam kedudukannya sebagai aparat penegak hukum mempunyai fungsi menegakkan hukum dibidang yudisial, tugas

\footnotetext{
${ }^{21}$ Ibid., hlm. 33.
} 
Rossi Suparman

Jurnal Hukum Mimbar Justitia

Vol. 6 No. 1 - Juni 2020

preventif maupun represif. Sehingga dengan dimilikinya kewenangan diskresi dibidang yudisial yang tertuang dalam UU No 2 tahun 2002 pada Pasal 18 ayat (1) bahwa "Untuk kepentingan umum pejabat Kepolisian Negara Republik Indonesia dalam melaksanakan tugas dan wewenangnya dapat bertindak menurut penilaiannya sendiri". Tentunya dalam melakukan tindakan tersebut harus sesuai dengan Pasal 4 UU No.2 Tahun 2002 yaitu dengan menjunjung tinggi hak asasi manusia.

Kemudian istilah Diskresi Kepolisian menurut Pasal 15 Ayat 2 huruf (k) dikenal dengan "kewenangan lain", menurut Pasal 16 Ayat (1) huruf I dikenal dengan "tindakan lain menurut hukum yang bertanggung jawab" dan menurut Pasal 7 ayat 1(j) KUHAP dikenal dengan istilah "tindakan apa saja menurut hukum yang bertanggung jawab".

Dalam tugas-tugas kepolisian khususnya tindakan penyelidikan dan penyidikan maka tindakan Diskresi Kepolisian harus memenuhi syarat sebagai berikut : a. Tidak bertentangan dengan suatu aturan hukum;

Artinya berjalan sesuai dengan hukum positif maupun hukum lainnya yang berlaku ditempat dimana Diskresi Kepolisian diambil oleh seorang petugas. Dalam sistem hukum di Indonesia dikenal 4 (empat) macam sumber hukum antara lain adalah Hukum Negara atau Hukum Positif, Hukum Adat Istiadat, Hukum Agama, dan Kebiasan-Kebiasaan.

b. Selaras dengan kewajiban hukum yang mengharuskan tindakan tersebut dilakukan;

artinya tindakan yang diambil diatur dalam aturan tertentu sebagai suatu kewajiban hukum untuk wajib ditegakkan.

c. Harus patut, masuk akal, dan termasuk dalam lingkungan jabatannya;

artinya dapat diterima dengan akal yang sehat bagi lingkungan dimana tindakan itu diambil.

d. Pertimbangan yang layak berdasarkan keadaan yang memaksa; 
Rossi Suparman

Jurnal Hukum Mimbar Justitia

Vol. 6 No. 1 - Juni 2020

artinya pada pelaksanaannya atau cara penyampaian dilapangan dilakukan berdasarkan kejadian yang hanya pada saat-saat tertentu (emergencies) tanpa pengamatan ataupun penelitian yang mendalam tentang apa yang diputuskannya tersebut.

e. Menghormati HAM.

Artinya sesuai dengan ketentuan HAM dan tidak melanggar ketentuan HAM tersebut.

Pasal 16 ayat 1 Undang- undang No. 2 Tahun 2002, pasal 18 UndangUndang No. 2 tahun 2002 dan pasal 7 ayat 1 sub (j) KUHAP bila tidak ada pembatasan yang jelas dan tegas, dapat disalahartikan pelaksanaan diskresi yang dapat menjurus pada tindakan penyimpangan diskresi kepolisian. Selain penerapan diskresi kepolisian harus mengacu pada peraturan perundang-undangan yang berlaku, diskresi pun dapat diberlakukan dengan mendasarkan pada hukum adat/kebiasaan setempat. Misalnya, di Bali seringkali penyelenggaraan kegiatan/upacara adat disertai dengan kegiatan sabung ayam, yang mana berdasarkan hukum pidana nasional, dapat dikategorikan sebagai tindakan perjudian sebagaimana diatur dalam Pasal 303 KUHP. Namun aparat kepolisian tidak serta merta menangkapi orang-orang yang sedang melakukan sabung ayam, sekalipun polisi memiliki wewenang untuk melakukannya. Akan tetapi dengan melihat bahwa kegiatan sabung ayam juga merupakan bagian dari kebudayaan/ adat Bali, Kepolisian menggunakan hak (diskresi) nya untuk tidak menangkap atau membubarkan orang-orang yang melakukan sabung ayam.

Perlu diperhatikan, sekalipun aparat kepolisian memiliki kewenangan bertindak atas dasar penilaiannya sendiri, hal ini tidak boleh ditafsirkan secara sempit, sehingga aparat kepolisian dengan mudah menerapkan kewenangan diskresi. Oleh karena itu, lahirnya diskresi tidak dapat dipisahkan dari adanya suatu wewenang kepolisian secara umum serta adanya hukum yang mengatur untuk bertindak, sehingga diskresi harus dilakukan dalam kerangka adanya wewenang yang 
Rossi Suparman

Jurnal Hukum Mimbar Justitia

Vol. 6 No. 1 - Juni 2020

diberikan oleh hukum. Terkait penerapan diskresi kepolisian dalam menyelesaikan kasus pidana, ada beberapa pertimbangan yang umum dijadikan pegangan, antara lain:

1. Mempercepat proses penyelesaian perkara. Hal ini dilakukan mengingat melalui jalur formal, perkara yang sedang diperiksa akan selesai dalam jangka waktu lama.

2. Menghindarkan terjadinya penumpukan perkara. Tugas dan tanggung jawab yang diemban oleh aparat kepolisian dari hari ke hari semakin bertambah, sehingga tindakan diskresi dapat digunakan sebagai sarana yang efektif untuk mengurangi beban pekerjaan.

Adanya keinginan agar perkara selesai secara win-win solution, mengingat melalui cara-cara formal dapat dipastikan akan ada pihak yang kalah dan ada yang menang; Adanya perasaan iba (belas kasihan) dari pihak korban, sehingga korban tidak menghendaki kasusnya diperpanjang.
Pada dasarnya, langkah diskresi kepolisian dilakukan sebagai bentuk tanggung jawab kepolisian yang diberikan negara. Misalnya dalam kasus tindak pidana yang pelakunya melibatkan anak-anak, seperti dalam kasus Narkoba. Anak-anak yang menjadi pemakai narkoba adalah korban perilaku orang dewasa yang berperan sebagai pengedar. Karena itu, pembinaan yang diterapkan terhadapnya tidak bisa disamakan dengan orang dewasa yang melakukan penyalahgunaan Narkoba. Disinilah kewenangan diskresi untuk dikedepankan karena jika perlakuan terhadap anak-anak disamakan dengan orang dewasa, dikhawatirkan justru akan berdampak negatif terhadap anak-anak di kemudian hari.

Pemidanaan terhadap anak-anak korban narkoba bukan merupakan jalan terbaik karena yang lebih penting adalah rehabilitasi dan pemulihan karena anak-anak adalah masa depan bangsa, terlebih Indonesia telah meratifikasi konvensi hak anak (Convention on The Right of Children), sehingga dengan telah diratifikasinya 
Rossi Suparman

Jurnal Hukum Mimbar Justitia

Vol. 6 No. 1 - Juni 2020

konvensi hak anak, Indonesia memiliki kewajiban untuk memenuhi hak-hak bagi semua anak tanpa terkecuali. Salah satu hak anak yang perlu mendapat perhatian dan perlindungan adalah hak anak yang berkonflik dengan hukum.

Menurut Adrianus Meliala, kasuskasus pidana yang potensial diselesaikan melalui upaya penyelesaian di luar pengadilan, termasuk di dalamnya dengan cara menerapkan diskresi, di antaranya: ${ }^{22}$

1. Kasus Penipuan dan penggelapan yang mana pelaku telah mengembalikan kerugian yang diderita korban;

2. Pelanggaran sebagaimana diatur dalam buku ketiga KUHP;

3. Tindak pidana ringan yang diancam dengan pidana penjara atau kurungan paling lama 3 (tiga) bulan atau denda sebanyakbanyaknya Rp 7.500 (tujuh ribu lima ratus rupiah);

4. Kejahatan ringan (lichte musjdriven) sebagaimana diatur dalam KUHP sebagai berikut;
a. Pasal
302
tentang
penganiayaan
ringan
terhadap hewan;
b. Pasal 352 tentang penganiayaan ringan terhadap manusia;
c. Pasal 364 tentang pencurian ringan;
d. Pasal 373 tentang penggelapan ringan;
e. Pasal 379 tentang penipuan;
f. Pasal 482 tentang penadahan ringan;
g. Pasal 315 tentang penghinaan ringan.

\section{Hubungkan Antara Pelaksanaan Diskresi Aparatur Sipil Negara dengan Diskresi yang dilakukan oleh Kepolisian.}

Diskresi sebagaimana yang disebutkan dalam Pasal 4 ayat (1) Undang-Undang Nomor 30 Tahun 2014 tentang Administrasi Pemerintahan disebutkan bahwa: Ruang lingkup pengaturan Administrasi Pemerintahan dalam undang-undang ini meliputi semua aktifitas:

22 Ibid, hlm. 41. 
Rossi Suparman

Jurnal Hukum Mimbar Justitia

Vol. 6 No. 1 - Juni 2020

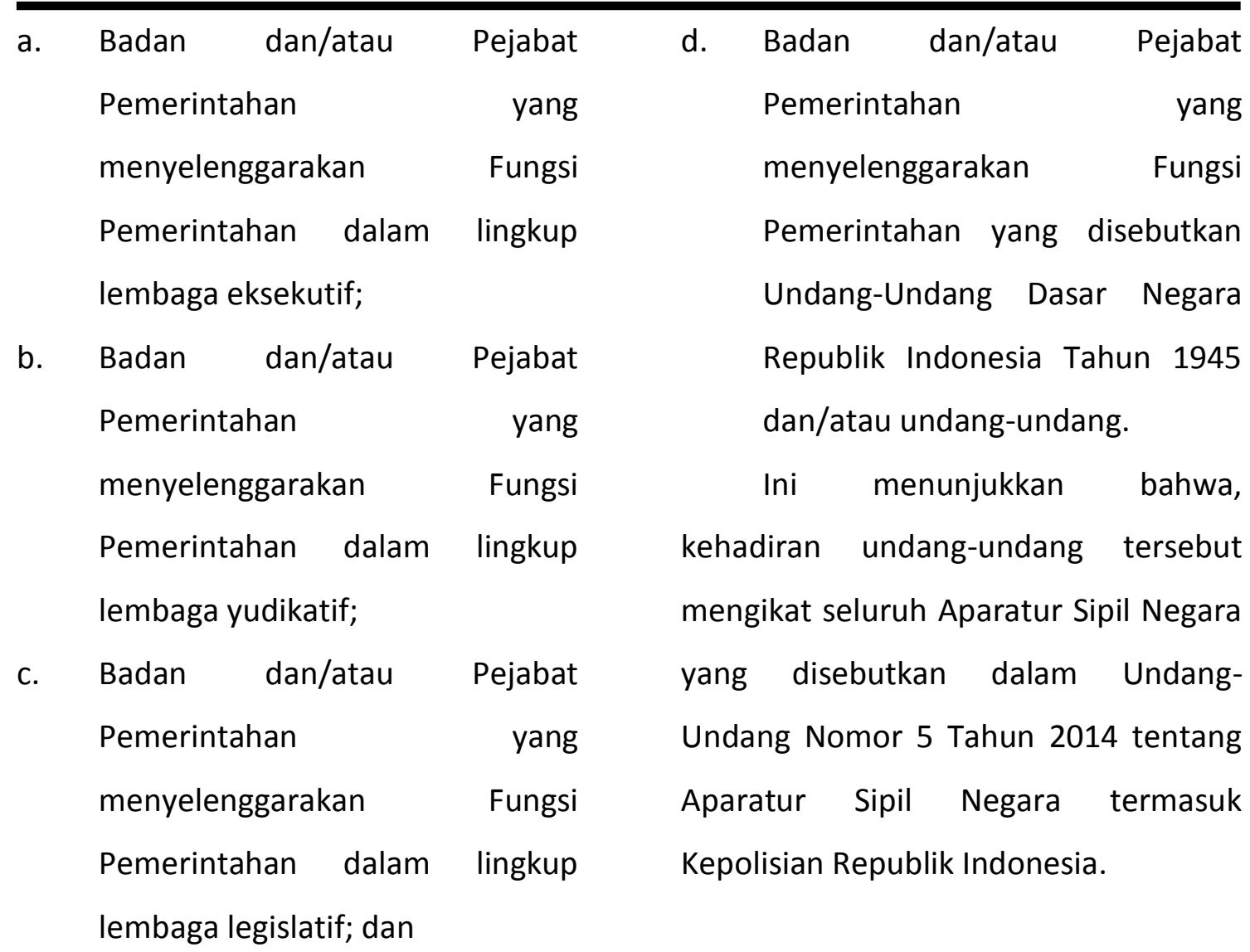

Gambar 4.3: Diskresi dilihat dari UU POLRI dan UU Administrasi Pemerintahan

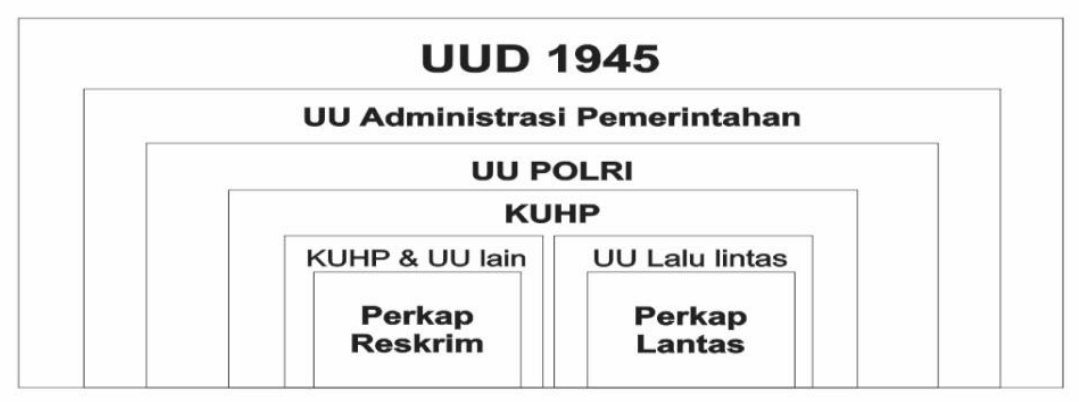

Skema tersebut di atas dapat dilihat bahwa ketika terjadi diskresi yang menerobos aturan di dalam PERKAP dan KUHAP berupa menangkap dan menahan seseorang yang dianggap meresahkan kelompok masyarakat tertentu dengan pertimbangan keamanan dan keselamatan, maka walaupun tindakan tersebut mengabaikan peraturan teknis yang ada namun pada dasarnya tidak bertentangan dengan undang-undang yang memberikan kewenangan yang lebih tinggi, yaitu kewenangan untuk 
Rossi Suparman

Jurnal Hukum Mimbar Justitia

Vol. 6 No. 1 - Juni 2020

memelihara keamanan dan ketertiban sebagaimana yang menjadi tugas pokok POLRI dan diamanatkan oleh konstitusi. Penafsiran yang berbeda-beda ini kemudian mengarah kepada pertanyaan apakah diskresi itu dilakukan dengan "menerobos" atau bahkan seolah-olah bertentangan dengan hukum, ataukah diskresi yang dilakukan tidak boleh bertentangan dengan peraturan perundangundangan yang berlaku?

Sebagaimana dikemukakan oleh Prayudi Atmosudirdjo bahwa terdapat dua jenis diskresi, yaitu (1) diskresi bebas, dimana setiap tindakan tidak perlu didasarkan atas ketentuan perundang-undangan; dan (2) diskresi terikat, dimana setiap tindakan adalah hasil pilihan dari beberapa alternatif yang terdapat didalam peraturan perundang-undangan, sehingga pemilihan salah satu alternatif adalah bebas. Dengan demikian dapat disimpulkan pemikiran dari Prayudi Atmosudirdjo bahwa diskresi menurutnya dapat dilakukan dengan menerobos undang-undang dan dapat juga dilakukan didalam undang-undang. Dengan demikian tidak dapat dihindari adanya pertentangan dan pengabaian diantara peraturan-peraturan yang bersifat teknis, namun masih tetap dalam koridor kewenangan POLRI yang lebih luas. Demikian juga tidak dapat dihindari adanya kewajiban untuk tidak bertentangan dengan koridor kewenangan POLRI yang lebih luas itu sendiri. Artinya diskresi yang dilakukan tidak boleh bertentangan dengan tujuan untuk memelihara keamanan dan ketertiban masyarakat. Apabila menghubungkan antara pasal 18, Pasal 16 ayat (1) huruf I dan ayat 2 UU Kepolisian, serta Pasal 5 dan 7 KUHAP, maka pemaknaan diskresi kepolisian dapat digambarkan sebagai berikut: 


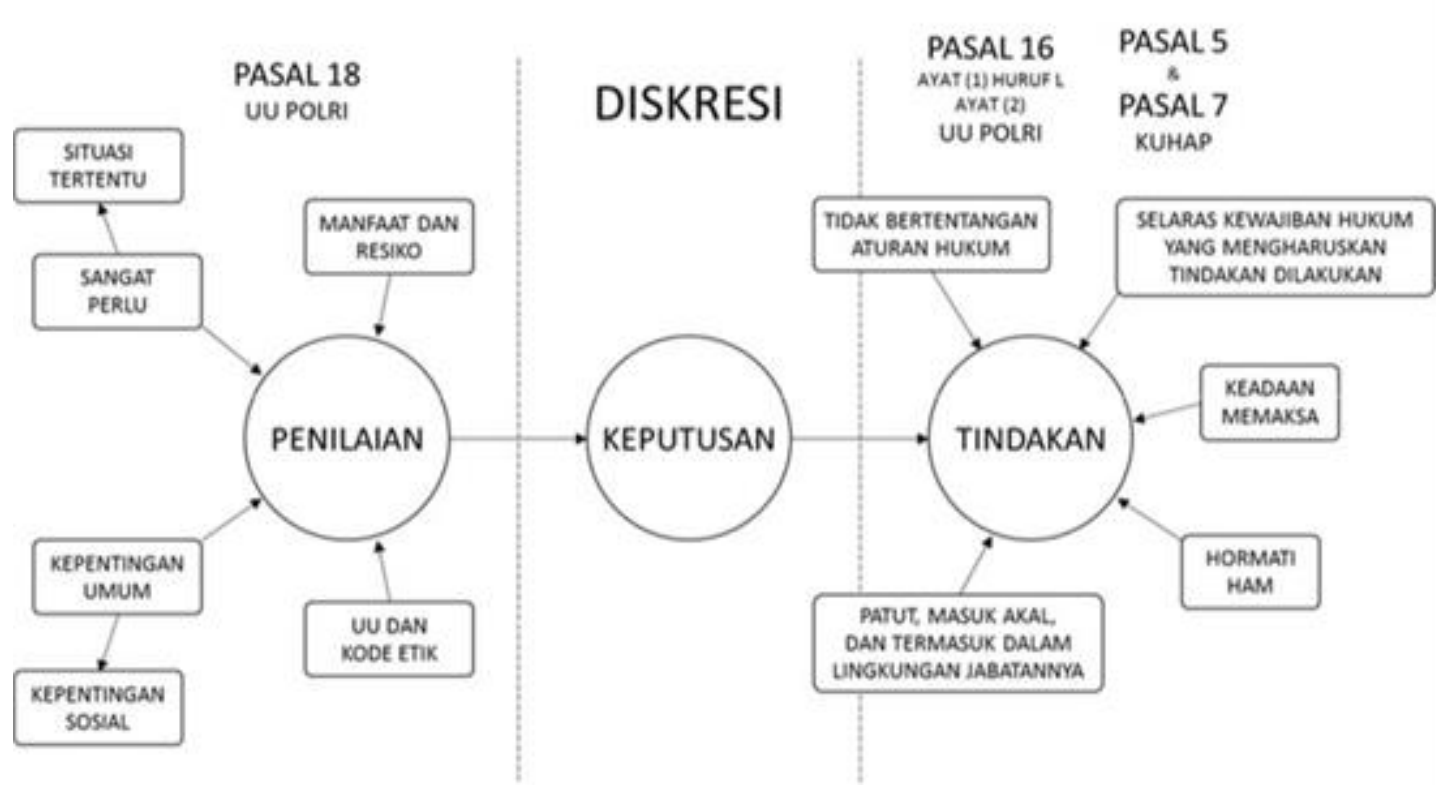

Berdasarkan gambaran di atas dapat dikatakan bahwa pada dasarnya diskresi adalah suatu keputusan terhadap pilihan tindakan yang didasarkan penilaian pribadi dengan pertimbangan moral, yang dilakukan dalam situasi tertentu serta demi kepentingan umum maupun kepentingan sosial. Dengan demikian yang dimaksud diskresi kepolisian adalah diskresi yang dilakukan dalam ruang lingkup pelaksanaan tugas kepolisian. Diskresi kepolisian terjadi ketika seorang petugas kepolisian dihadapkan pada pengambilan keputusan saat terdapat berbagai pilihan tindakan. Sedangkan yang dimaksud diskresi kepolisian dalam penyidikan tindak pidana adalah diskresi yang dilakukan oleh penyidik dalam tataran teknis penyidikan maupun mengabaikan tataran teknis penyidikan dengan tetap memperhatikan prosedur dan peraturan perundang-undangan, yang bertujuan untuk memelihara keamanan dan ketertiban masyarakat.

Selain diskresi yang dilakukan dalam tataran fungsional kepolisian, terdapat pula diskresi yang dilakukan untuk membantu kelancaran dan mengatasi hambatan dalam proses 
Rossi Suparman

Jurnal Hukum Mimbar Justitia

Vol. 6 No. 1 - Juni 2020

penyidikan. Hal ini tercermin dalam

diskresi yang dilakukan pejabat

pemerintahan sebagaimana diatur

dalam Undang-Undang Nomor 30
Tahun 2014 Tentang Administrasi

Pemerintahan. Diskresi menurut undang-undang ini dapat digambarkan sebagai berikut :

Gambar 4.5 : Diskresi menurut Undang-Undang Administrasi Pemerintahan

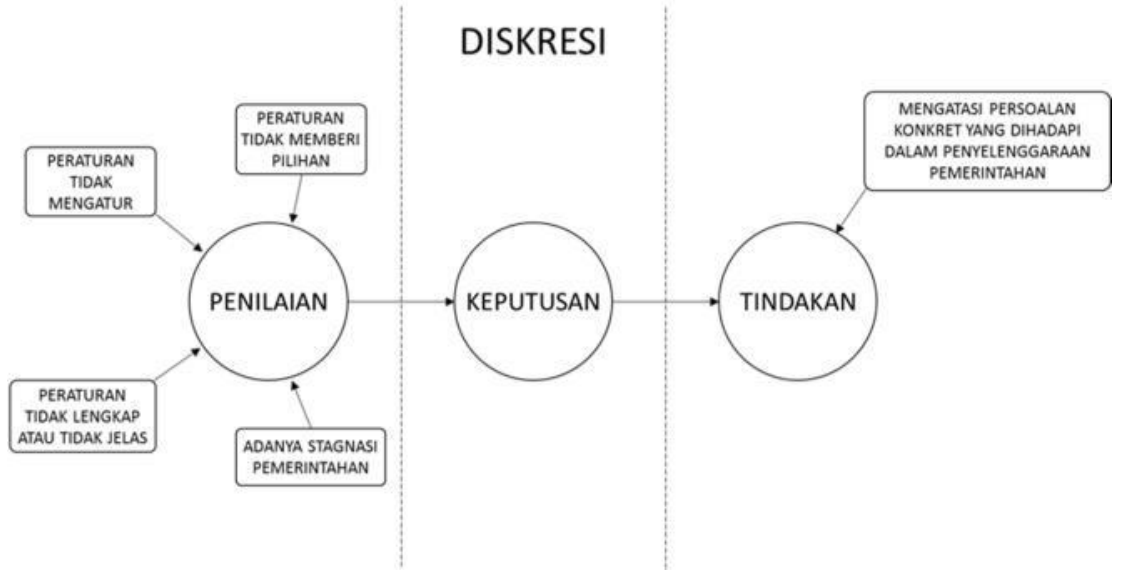

Berdasarkan gambaran tersebut

di atas dapat dilihat bahwa dalam

hubungan antara pelaksanaan diskresi

menurut Undang-Undang Nomor 30

tahun 2014 tentang Administrasi

Pemerintahan dengan Undang-undang

Nomor 2 Tahun 2002 tentang

Kepolisian Republik Indonesia adalah

terdapat perluasan tujuan diskresi

kepolisian dalam penegakan hukum,

yaitu tidak hanya untuk menciptakan

dan memelihara keamanan dan

ketertiban, melainkan juga untuk

melancarkan dan mengatasi hambatan

dalam proses penegakan hukum.
IV. PENUTUP

A. Kesimpulan

1. Bahwa diberlakukannya UndangUndang Nomor 30 tahun 2014 tentang

Administrasi

Pemerintahan merupakan bentuk upaya memberikan kedudukan hukum bagi diskresi yang ada di lingkungan Aparatur Sipil Negara. Diskresi diatur lebih jelas, ada dalam 16 Pasal di dalam undangundang tersebut mulai dari definisi, batasan sesuai undangundang, batasan dikeluarkan oleh 
Pejabat yang berwenang, tujuan, lingkup, syarat, penggunaan diskresi dan prosedur persetujuan, dan akibat hukum diskresi.

2. Bahwa POLRI dalam kedudukannya sebagai aparat penegak hukum mempunyai fungsi menegakkan hukum di bidang yudisial baik itu yang bersifat preventif maupun represif. Sehingga dengan dimilikinya kewenangan diskresi dibidang yudisial yang tertuang dalam UU No 2 tahun 2002 pada Pasal 18 ayat (1) bahwa "Untuk kepentingan umum pejabat Kepolisian Negara Republik Indonesia dalam melaksanakan tugas dan wewenangnya dapat bertindak menurut penilaiannya sendiri”.

3. Berdasarkan gambaran tersebut di atas dapat dilihat bahwa dalam hubungan antara pelaksanaan diskresi menurut Undang-Undang Nomor 30 tahun 2014 tentang administrasi pemerintahan dengan Undang-undang Nomor 2
Tahun 2002 tentang Kepolisian Republik Indonesia adalah terdapat perluasan tujuan diskresi kepolisian dalam penegakan hukum, yaitu tidak hanya untuk menciptakan dan memelihara keamanan dan ketertiban, melainkan juga untuk melancarkan dan mengatasi hambatan dalam proses penegakan hukum.

\section{B. Saran}

1. Meskipun lebih baik karena diskresi sudah diatur dalam undang-undang, namun pemaknaannya dan pengaturannya masih membuka ruang lebar untuk berbagai interpretasi. Sehingga masih diperlukan undang-undang lain yang memiliki ruang spesifik untuk menutup ruang tersebut dengan tidak bertentangan dengan Undang-Undang Nomor 30 Tahun 2014 tentang Administrasi Pemerintahan.

2. Diperlukan suatu aturan khusus mengenai diskresi kepolisian 


\begin{tabular}{llr} 
& & $\begin{array}{r}\text { Ross } \\
\text { Jurnal Huk } \\
\text { Vol. 6 }\end{array}$ \\
\hline khususnya & dalam & bidang \\
penyidikan $\quad$ tindak & pidana \\
sehingga tidak menimbulkan & \\
keragu-raguan atau perdebatan \\
dalam pelaksanaannya baik \\
secara internal maupun dari \\
eksternal POLRI.
\end{tabular}

\section{DAFTAR PUSTAKA}

A. Buku.

Amrah Muslimin, 1985, Beberapa Asas dan Pengertian Pokok Tentang Administrasi dan Hukum Administrasi, Alumni, Bandung.

C.S.T. Kansil, 1979, Pokok-Pokok Hukum Kepegawaian Republik Indonesia, Pradnya Paramitha, Jakarta.

Erlyn, 2000, Diskresi Polisi, Lembaga Penerbit Universitas Diponegoro, Semarang.

Henny Nuraeny, 2017, Tindak Pidana Perdagangan Orang dalam Prespektif Hak Asasi Manusia, Rajawali, Jakarta Pusat.

M. Rendi Aridhayandi dkk, 2016, Teori Hukum Lanjutan, Logoz Publishing, Bandung.

Moh Mahfud MD, 2000, Dasar dan Struktur Ketatanegaraan Indonesia (Edisi Revisi), Renaka Cipta, Jakarta. ossi Suparman

Hukum Mimbar Justitia

l. 6 No. 1 - Juni 2020
Muchsan, 2007, Sistem Pengawasan Terhadap Perbuatan Aparat Pemerintah dan PTUN, Liberty, Yogyakarta.

Mukti Fajar dan Yulianto Achamd, 2010, Dualisme Penelitian Hukum Normatif dan Empiris, Pustaka Pelajar, Yogyakarta.

Patuan Sinaga, Hubungan Antara Kekuasaan dengan Pouvoir Discretionnere dalam Penyelenggaraan Pemerintahan, dalam S.F Marbun dkk., 2004, Dimensi-Dimensi Pemikiran Hukum Administrasi Negara, UII Press, Yogyakarta.

Ridwan, H.R., 2003, Hukum Administrasi Negara, UII Press, Yogyakarta.

Satjipto Rahardjo, 1983, Masalah Penegakan Hukum, Sinar Baru, Bandung.

Simorangkir, dkk, 2004, Kamus Hukum, Sinar Grafika.Susanto, Jakarta, dalam Anthon F, 2010, Wajah Peradilan Kita, Refika Aditama, Bandung.

Soerjono Soekanto \& Sri Mamudji, 1985, Penelitian Hukum Normatif (Suatu Tinjauan Singkat), Rajawali Pers, Jakarta.

B. Peraturan Perundang-Undangan. 
Rossi Suparman

Jurnal Hukum Mimbar Justitia

Vol. 6 No. 1 - Juni 2020

Undang-Undang Dasar Negara Republik Indonesia Tahun 1945.

Undang - Undang Nomor 30 Tahun 2014 tentang Administrasi

Pemerintahan.

\section{Jurnal, dan Disertasi.}

Ahmad Hunaeni Zulkarnaen, 2016, Cita Hukum Positif Indonesia dan Asean Economic Community $(A E C)$, Jurnal Hukum Mimbar Justitia, Vol. 2 No. 1, Fakultas Hukum Universitas Suryakancana, Cianjur.
M. Rendi Aridhayandi, 2019, Kewenangan Pemerintah Daerah Dalam Pembinaan dan Pengawasan Indikasi Geografis Beras Pandanwangi Cianjur, Disertasi, Program Pascasarjana Doktor IImu Hukum Universitas Katolik Parahyangan, Bandung.

Tanti Kirana Utami, 2013, Peran Serikat Pekerja Dalam Penyelesaian Perselisihan Pemutusan Hubungan Kerja, Jurnal Wawasan Hukum, Vol. 28 No. 1, Sekolah Tinggi Hukum Bandung, Bandung. 